\title{
Natural enemies of the fall armyworm Spodoptera frugiperda (Smith) (Lepidoptera: Noctuidae) in Burkina Faso
}

Besmer Régis Ahissou, Wendnéyidé Mathieu Sawadogo, Schémaéza Bonzi, Hugues Baimey, Irénée Somda, Aimé H. Bokonon-Ganta \& François J. Verheggen

Besmer Régis Ahissou : Beninese. Professional Master in Plant Protection and PhD student at Gembloux Agro-Bio Tech (University of Liege, Belgium) and at the Institute of Rural Development (University Nazi Boni, Bobo-Dioulasso, Burkina Faso). Email: besmernic@gmail.com

Wendnéyidé Mathieu Sawadogo : Burkinabé. Engineer in Agronomy and PhD student at Gembloux Agro-Bio Tech (University of Liege, Belgium) and at the Institute of Rural Development (University Nazi Boni, Bobo-Dioulasso, Burkina Faso). Email: waugoimathieu@yahoo.fr

Schémaéza Bonzi : Burkinabé. Engineer in Agronomy and Doctor in phytopathology, Assistant Professor in phytopathology at University Nazi Boni, Bobo-Dioulasso, Burkina Faso. Email: ouakobonzi@yahoo.fr

Hugues Baimey : Beninese. MSc and PhD in nematology, Professor in nematology at University of Parakou, Parakou, Benin. Laboratory of Diagnosis and Integrated Management of Plant Bioagressors, Faculty of Agronomy. Email: baimeyhugues@gmail.com

Irénée Somda : Burkinabé, Engineer in Agronomy and Doctor in phytopathology, Professor in phytopathology at University Nazi Boni, Bobo-Dioulasso, Burkina Faso. Email: ireneesomda@yahoo.fr

Aimé H. Bokonon-Ganta : Beninese. Engineer in Agronomy and Doctor in Entomology, Lecturer in phytopathology at University of Abomey-Calavi, Abomey-Calavi, Benin. Laboratory of Agricultural Entomology, Faculty of Agronomic Sciences. Email: aimehbg@gmail.com

François J. Verheggen : Belgian. Bioengineer and Doctor in Agronomic Sciences and biological engineering. Professor of Entomology at Gembloux Agro-Bio Tech (University of Liege). Avenue de la Faculté d'Agronomie 2B, 5030 Gembloux, Belgium. Corresponding Author:

fverheggen@uliege.be; Tel: +3281622662

DOI: $10.25518 / 2295-8010.1881$

Résumé :

La chenille légionnaire d'automne Spodoptera frugiperda (Lepidoptera: Noctuidae) est un ravageur vorace qui se nourrit principalement de céréales et autres cultures d'importance économique. Originaire d'Amérique, elle a récemment envahi les pays d'Afrique sub-saharienne où elle menace actuellement la sécurité alimentaire. Les connaissances sur ses ennemis naturels en Afrique sont limitées. Dans cette étude, nous avons cherché à identifier les arthropodes, les champignons et les nématodes entomopathogènes qui contrôlent naturellement ce ravageur au Burkina Faso. Des échantillonnages d'insectes, y compris des larves et des masses d'œufs, ont été réalisés dans 47 champs de maïs d'octobre 2019 à novembre 2020. Une vingtaine d'espèces 
Natural enemies of the fall armyworm Spodoptera frugiperda (Smith) (Lepidopte...

de parasitoïdes, de prédateurs et de champignons entomopathogènes associés à la chenille légionnaire d'automne ont été identifiées. Le taux de parasitisme global était de 10,5\%. Les nématodes (Mermithidae) étaient les parasites les plus fréquents (73,2\% des larves parasitées). Les parasitoïdes identifiés comprenaient des Hyménoptères [Coccygidium luteum (Brullé), Chelonus bifoveolatus (Szépligeti)] et des Diptères (Drino sp.). Les prédateurs comprenaient des Areneae et des insectes appartenant aux familles suivantes : Carabidae (Calleida sp.), Coccinellidae [Cheilomenes sulphurea (Olivier)], Forficulidae [Diaperasticus erythrocephalus (Olivier), Forficula senegalensis (Serville)], Formicidae [Pheidole megacephala (Fabricius) et autres], Mantidae, Pentatomidae et Reduviidae (Rhynocoris sp.). Les prédateurs les plus abondants étaient les Forficulidae (51\%), Formicidae (15\%) et Coccinellidae (13\%). Nous préconisons le développement de la lutte biologique de conservation, car cette approche peut être simple et rentable pour contrôler ce ravageur.

Mots-clés : lutte biologique, champignon entomopathogène, nématode entomopathogène (Mermithidae), prédateurs généralistes, parasitoïdes

\section{Abstract :}

The fall armyworm Spodoptera frugiperda (Lepidoptera: Noctuidae) is a voracious pest that preferentially feeds on cereals and other crops of economic importance. Native to America, it has recently invaded sub-Saharan African countries where it is currently threatening food security. There is limited knowledge of the natural enemies of the fall armyworm in Africa. In this study, we aimed to identify arthropods, fungi and entomopathogenic nematodes that naturally control this pest in Burkina Faso. Insect samplings, including larvae and egg masses, were conducted in 47 maize farms from October 2019 to November 2020. About 20 species of parasitoids, predators and entomopathogenic fungus associated with the fall armyworm were identified. The overall parasitism rate was $10.5 \%$. Nematodes (Mermithidae) were the most frequent parasites (73.2\% of the parasitized larvae). Identified parasitoids included Hymenopterans [Coccygidium luteum (Brullé), Chelonus bifoveolatus (Szépligeti)] and Dipterans (Drino sp.). Predators included Areneae and insects belonging to the following families: Carabidae (Calleida sp.), Coccinellidae [Cheilomenes sulphurea (Olivier)], Forficulidae [Diaperasticus erythrocephalus (Olivier), Forficula senegalensis (Serville)], Formicidae [Pheidole megacephala (Fabricius) and others], Mantidae, Pentatomidae and Reduviidae (Rhynocoris sp.). The most abundant predators were members of the Forficulidae (51\%), Formicidae (15\%) and Coccinellidae (13\%). We advocate for the development of conservation biological control since this approach can be simple and cost-effective to control this pest.

Keywords : biological control, entomopathogenic fungus, entomopathogenic nematode (Mermithidae), generalist predators, parasitoids

\section{Introduction}

Native from tropical America, Spodoptera frugiperda (Smith) (Lepidoptera: Noctuidae), commonly known as fall armyworm invaded West Africa in early 2016 (1). It is a major insect pest of maize and other cereals that has spread rapidly across the African continent $(2,3)$ and then to Asia where it was first reported in India $(4,5)$. In the absence of control measures, the fall armyworm can cause estimated maize yield losses of 8 - 20 million tons in 12 African countries per year (6). Following serious infestations in West Africa, fall armyworm management has been based primarily on the use of chemical insecticides, despite their questionable and unproven efficacy (7-9) or unregistered 
for use on this new threat (8). The adverse effects of some chemical insecticides on human health, the environment, and living organisms (10) makes biological control a more desirable alternative to control this pest in the long term (7).

The beneficial action of competitors, pathogens, parasitoids and predators in the control of pests and their damage is termed biological control (11). Four types of biological control strategies applied in pests control programs may be identified: natural (no human intervention), augmentative (periodical release of mass-reared natural enemies), classical (importation of an exotic natural enemy), and conservation biological control $(2,11,12)$. Conservation biological control, i.e. the conservation of existing natural enemies in an environment, can be simple and cost-effective, through the manipulation of environment, cropping systems, and locally available techniques to enhance their efficacy $(7,11)$. It provides the possibility of minimizing pest outbreaks in an ecologically and economically cost effective manner using locally available natural enemies (13). However, its promotion should be based on a comprehensive knowledge of the diversity and abundance of natural enemies existing locally.

The fall armyworm is attacked by various natural enemies including insect parasitoids species $(14,15)$, diverse taxa of predators $(7,16,17)$ and entomopathogens such as fungi, bacteria, viruses and nematodes $(4,14,18)$. Natural enemy complex is reported as important mortality factors for the fall armyworm (up to $42 \%$ ) in its native continent (19). Natural enemies native to West Africa are already controlling other species of Spodoptera present in the area, including Spodoptera exempta (Walker), S. littoralis (Boisduval), S. litura (Fabricius), S. exigua (Hübner) (all Lepidoptera: Noctuidae). They may widen their niche by adapting to $S$. frugiperda as a novel host or prey $(17,20)$.

Presently, little information is available on natural enemies of the fall armyworm in Africa (21) and Asia (22). Although, some recent studies reported natural enemies of fall armyworm in Tanzania, Kenya and Ethiopia (15), Senegal (18), Benin, Ivory Coast and Ghana $(17,21,23)$, Niger (24), Mozambique (25) and India $(4,20,22)$. These studies indicated that the natural enemy complex associated with fall armyworm varies between countries, even though some species (i.e., Coccygidium spp., Chelonus spp., Campoletis spp., Metopius spp., Trichogramma spp., Telenomus sp., Hexamermis sp. and earwigs) have been widely reported in many parts of the world.

In Burkina Faso, such information is lacking from the scientific literature, although S. frugiperda is extremely active in the country. Farmers have a detailed knowledge of most of the arthropod present in their field. However, they usually cannot identify the beneficial role of many of them (26). In this study, we documented the natural enemies of fall armyworm and evaluated their contributions to pest mortality.

\section{Materials and methods}

\section{Sampling sites and methods}

This study investigated the natural enemies of fall armyworm larvae by collecting its larvae and eggs, and by counting and identifying all species of predatory arthropods in maize fields in Burkina Faso. A total of 47 maize fields were sampled from two producing provinces of the country: Houet $\left(11^{\circ} 20^{\prime} \mathrm{N}, 4^{\circ} 15^{\prime} \mathrm{W}\right)$ and Kadiogo $\left(12^{\circ} 20^{\prime} \mathrm{N}, 1^{\circ} 30^{\prime} \mathrm{W}\right.$ ) (Fig. 1) from October 2019 to November 2020. Provinces of Houet and Kadiogo were selected based on reported presence of fall armyworm 
Natural enemies of the fall armyworm Spodoptera frugiperda (Smith) (Lepidopte...

combined with maize production in the Sudanian and Sahelo-Sudanese agro-ecological zones, respectively. Maize, sorghum, and other cereals are typically grown in the province of Houet. Agriculture in the province of Kadiogo is characterized by intensive horticulture: maize, tomato, cabbage, and other vegetable crops are grown year-around.

In the different fields, the presence of fresh frass and feeding injury on whorls and leaves helped locate sites with fall armyworm infestation. Only maize fields in which plants were in stages V5 (2 fully deployed leaves) to R (tasseling and silking) were sampled (2). Among the plants having visible fall armyworm attack symptoms, 25 were randomly selected. Stalks, whorls, and both upper and lower surfaces of plant leaves were inspected. All fall armyworm egg masses and larvae found on the selected maize plants were collected. In addition, some entomopathogenic nematodes were directly observed on maize leaves and were collected with a fine brush. Predators present on the different parts of the plant were counted. The predation of fall armyworm was confirmed by direct observation in the field. Each field was visited once during the study period and location details such as latitude, altitude and longitude were taken using GPS. All samples were brought to the laboratory at the Training and Research Center of the University Nazi Boni (UNB) in Bobo Dioulasso (Burkina Faso) for rearing and identification. 

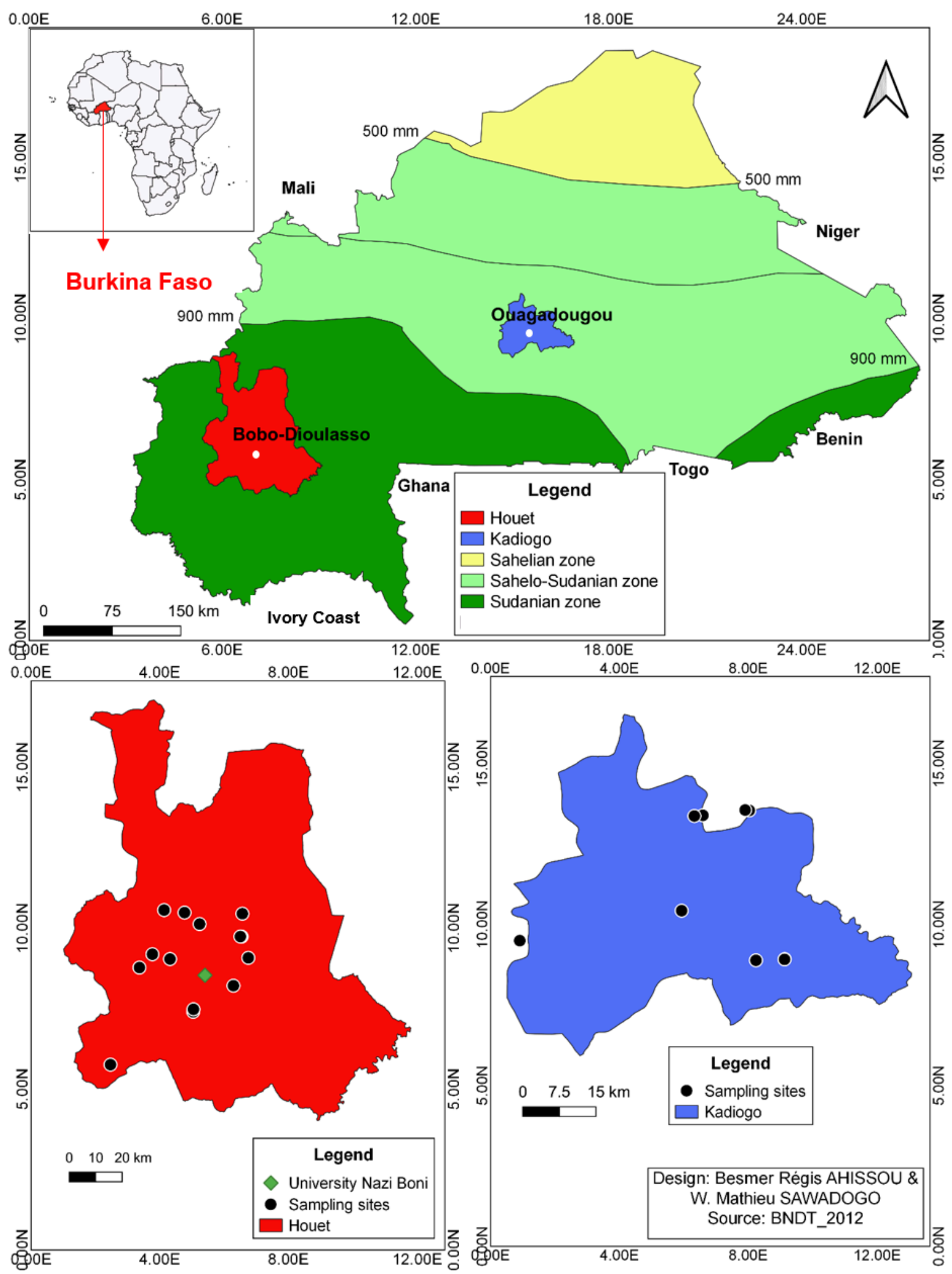

Figure 1: Sampling locations in Houet and Kadiogo provinces (Burkina Faso)

\section{Rearing of fall armyworm and natural enemies}

Fall armyworm egg masses were maintained separately in rearing containers until the emergence 
Natural enemies of the fall armyworm Spodoptera frugiperda (Smith) (Lepidopte...

of larvae or egg parasitoids. All collected insects were kept individually in the laboratory on maize leaves at $26 \pm 2^{\circ} \mathrm{C}, 71 \pm 14 \%$ relative humidity, and 12:12 photoperiod. Fall armyworm larvae development was checked every daily and fresh leaves were replaced after $24 \mathrm{~h}$ until pupation. They were observed until the emergence of fall armyworm imago, entomopathogenic nematodes or parasitoids.

Emerged parasitoids were preserved in 90\% ethanol and later identified morphologically. Entomopathogenic nematodes were grouped per date of collection in $250 \mathrm{ml}$ transparent plastic boxes containing moistened sand. Arthropod predators were observed and counted in the field. However, in doubtful cases, a sample of the predators were brought to the laboratory and exposed to fall armyworm eggs and to first, second, third and fourth (L1, L2, L3 and L4) instar larvae as prey, to check their predatory potential. All predators were then preserved in $90 \%$ ethanol until identification.

\section{Identification of natural enemies of the fall armyworm}

Entomopathogenic nematodes were sent for morphological identification in the Laboratory of Diagnosis and Integrated Management of Plant Bio-agressors at the University of Parakou (Benin). The determination keys and description proposed by Baker \& Capinera (27); Firake \& Behere (22) and Tendeng et al. (18) were used for their identification. For parasitoids, various determination keys were used to identify Braconidae (28-30) and Tachinadae $(31,32)$. For predators, the checklist of the earwigs of Chad (Dermaptera) (33) and determination keys proposed by Brindle (34) and Waller et al. (35) were used to identify Forficulidae. Online databases provided by Global Biodiversity Information Facility (GBIF: https://www.gbif.org/) and annotated list of ladybirds of Reunion Island (36) were used to identify Coccinellidae and Carabidae. The determination keys proposed by Kwadjo et al. (37) was used to identify Reduviidae.

\section{Entomopathogenic fungi isolation and Koch's postulates}

Cadavers of fall armyworm showing natural symptoms of entomopathogenic fungi were encountered and brought to the laboratory. Each cadaver was placed in a Petri dish containing Potato Dextrose Agar (PDA) medium and incubated at $25 \pm 2{ }^{\circ} \mathrm{C}$ and 12: $12 \mathrm{~h}$ (UV: dark) photoperiod for 7-14 days. After the incubation, the fungal conidia were harvested by scraping the conidial layers formed on the surface of the plates using a sterilized scalpel. To confirm the causal agent of the death of the fall armyworm, we evaluated the pathogenicity of isolated entomopathogenic fungi by confirming the Koch's postulates. The fungal conidia were dissolved in $0.05 \%$ Tween-20 solution and was inoculated to fall armyworm larvae (L3 and L5) by two methods. A larva dipping in an inoculum solution and a standard leaf dipping bioassay. A total of 40 larvae were observed per instar and method.

\section{Relative abundance and parasitism rates}

The number of fall armyworm collected was corrected by subtracting the number that died from injury or unknown causes during the first few days after collection before calculating percent parasitism (38). Unknown death causes may include possible bacteria, viruses, or the effects of chemical pesticides. Mortality due to parasitoids and nematodes was reported elsewhere. The relative abundance (RA) of each species was determined by dividing the number of individuals of a 
given species i $(\mathrm{Ni})$ by the total number of all individuals collected $(\mathrm{Nt})$ and expressing this value as a percentage (21). To assess RA, all predators were separated from the parasite group (i.e., parasitoids and nematodes). For the entomopathogenic fungi, numbers of field-infected larvae and total fall armyworm larvae collected were recorded and converted to percentage infection.

\section{$\mathrm{RA}=\frac{N i}{N t} \times 100$}

Gregarious parasitoids emerging from a single larva were considered as being only one. Parasitism rate (PR) of each parasitoid species was calculated by dividing the number of larvae parasitized (Lp) by the total number of fall armyworm larvae collected (TL) and by expressing this value as a percentage (39).

\section{$\mathrm{PR}=\frac{L p}{T L} \times 100$}

\section{Results}

Despite its recent introduction into West Africa, we recorded a total of 20 species of natural enemies associated with the fall armyworm, including parasitoids (5), predators (13), an entomopathogenic nematode (1) and an entomopathogenic fungus (1) in Houet and Kadiogo provinces of Burkina Faso (Table 1). A total of 23 fall armyworm egg masses were collected, but no egg parasitoids were detected. Out of 684 fall armyworm larvae collected, 47 died without any emergence of parasites or parasitoids. From the remaining 637 larvae, 67 contained entomopathogenic nematodes and parasitoids. Entomopathogenic nematodes (Nematoda: Mermithidae) were by far the most abundant species with RA estimated at 73.2\%. All other larval parasitoids were found to be less abundant (RA $<5 \%$ ) (Table 2). The overall parasitism rate was 10.5\% (Table 3). The predator complex is made of Araneae, and several insect families including Carabidae, Coccinellidae, Forficulidae, Formicidae, Mantidae, Pentatomidae and Reduviidae. This complex was dominated numerically by Forficulidae (51\%), followed by Formicidae (15\%) and Coccinellidae (13\%). All other predators were found to be less abundant (RA < 5\%). A total of thirteen species of predators were observed associated with different stages of fall armyworm (Table 4). In addition, nine cadavers of fall armyworm infected with fungi were found in seven maize fields. 
Natural enemies of the fall armyworm Spodoptera frugiperda (Smith) (Lepidopte...

Table 1: Provinces with the collected natural enemies of fall armyworm in Bukina Faso

\begin{tabular}{cc}
\hline Province & Natural enemies \\
\hline & Araneae, Calleida sp., Carabidae, Cheilomenes sulphurea, Chelonus \\
bifoveolatus, Coccygidium luteum, Diaperasticus erythrocephalus, Drino sp., \\
Entomopathogenic nematode, Forficula senegalensis, Mantidae, \\
Pentatomidae, Pheidole megacephala and other ants (Formicidae), \\
Rhynocoris sp., Unidentified gregarious endoparasitoid, Entomopthogenic \\
fungi on cadavers of fall armyworm \\
\hline Kadiogo & Ants (Formicidae), Araneae, Carabidae, C. sulphurea, D. erythrocephalus, F. \\
& senegalensis, Mantidae, Pentatomidae, Rhynocoris sp., Unidentified fly \\
& (Diptera), Entomopthogenic fungi on cadavers of fall armyworm \\
\hline
\end{tabular}

\section{Entomopathogenic nematodes}

Fifty-two larvae were parasitized by entomopathogenic nematodes (Nematoda: Mermithidae) (Fig. 2). All fall armyworm larvae died after nematode emergence. In the field, one entomopathogenic nematode emerged from fall armyworm larva was directly found in maize leave (Fig. 2b). 
Table 2: Host stages attacked and relative abondance (RA) of parasitoid and parasite of fall armyworm, recorded in maize fields located in Burkina Faso

\begin{tabular}{lccc}
\hline No & Order, family and species of parasitoid or \\
parasite & Type & RA \\
(\%)
\end{tabular}

The parasitism rate was calculated to be $8.2 \%$ (Table 3). The mermithids are white, 140-258 mm in length (Fig. 2d), and were living for more than 200 days in the laboratory. After reproduction in moistened sand in laboratory, infective juveniles of less than $10 \mathrm{~mm}$ in length were obtained (Fig. 2c). 


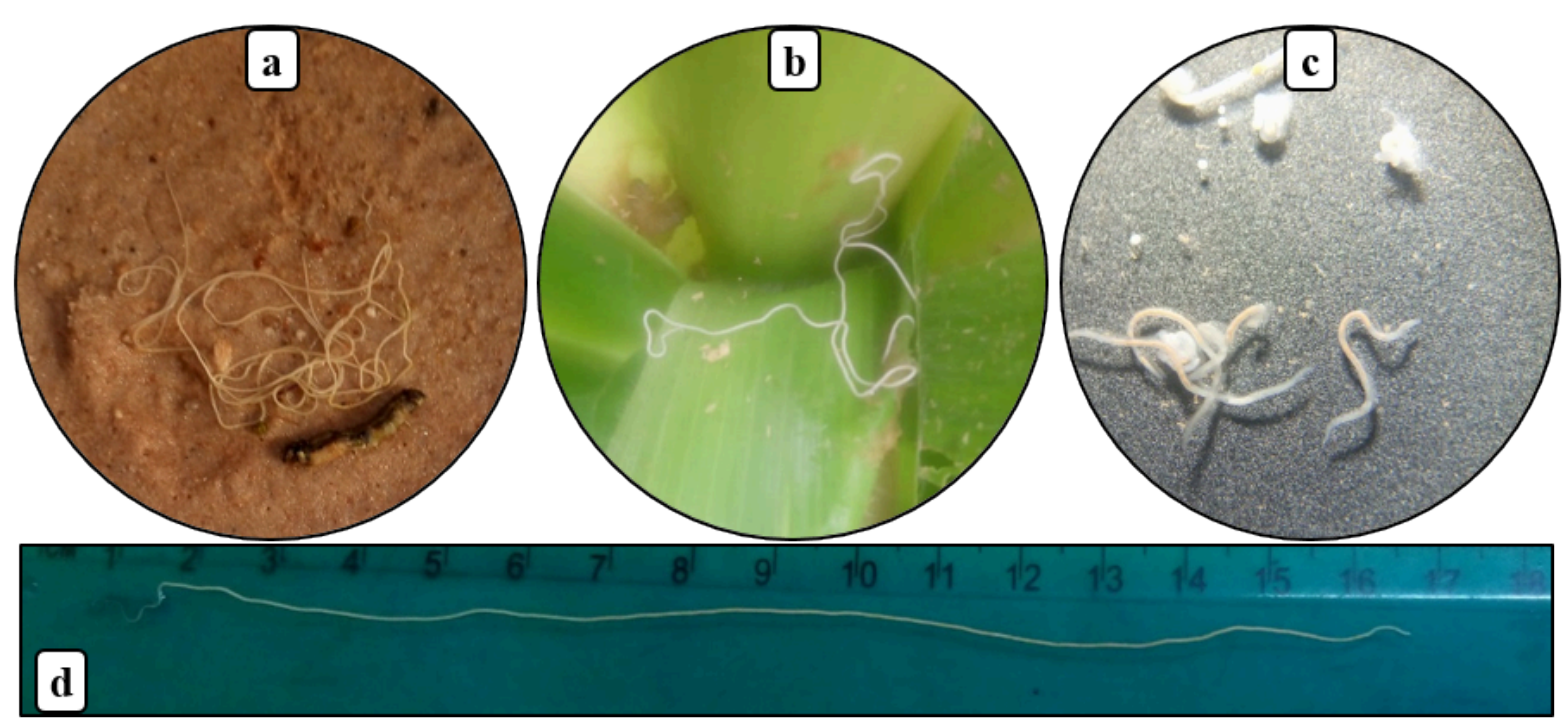

Figure 2: Mermithid nematode emerged from fall armyworm larvae

(a) nematode in soil, (b) nematode emerged from host on maize leaf, (c) infective juveniles of mermithid, (d) ruler graduated in cm used to measure nematodes

\section{Parasitoids}

From all samples of fall armyworm larvae collected, five species of parasitoids belonging to Hymenoptera (2), Diptera (2) and an unidentified gregarious larval endoparasitoid emerged (adults had not emerged from the parasitoid pupae) (Fig. 3a-f). These are Coccygidium luteum (Brullé), Chelonus bifoveolatus (Szépligeti) (both Braconidae), Drino sp. (Tachinidae), an unidentified diptera fly. Except for $C$. bifoveolatus, an egg-larval parasitoid, the others are exclusive larval parasitoids (Table 2). 


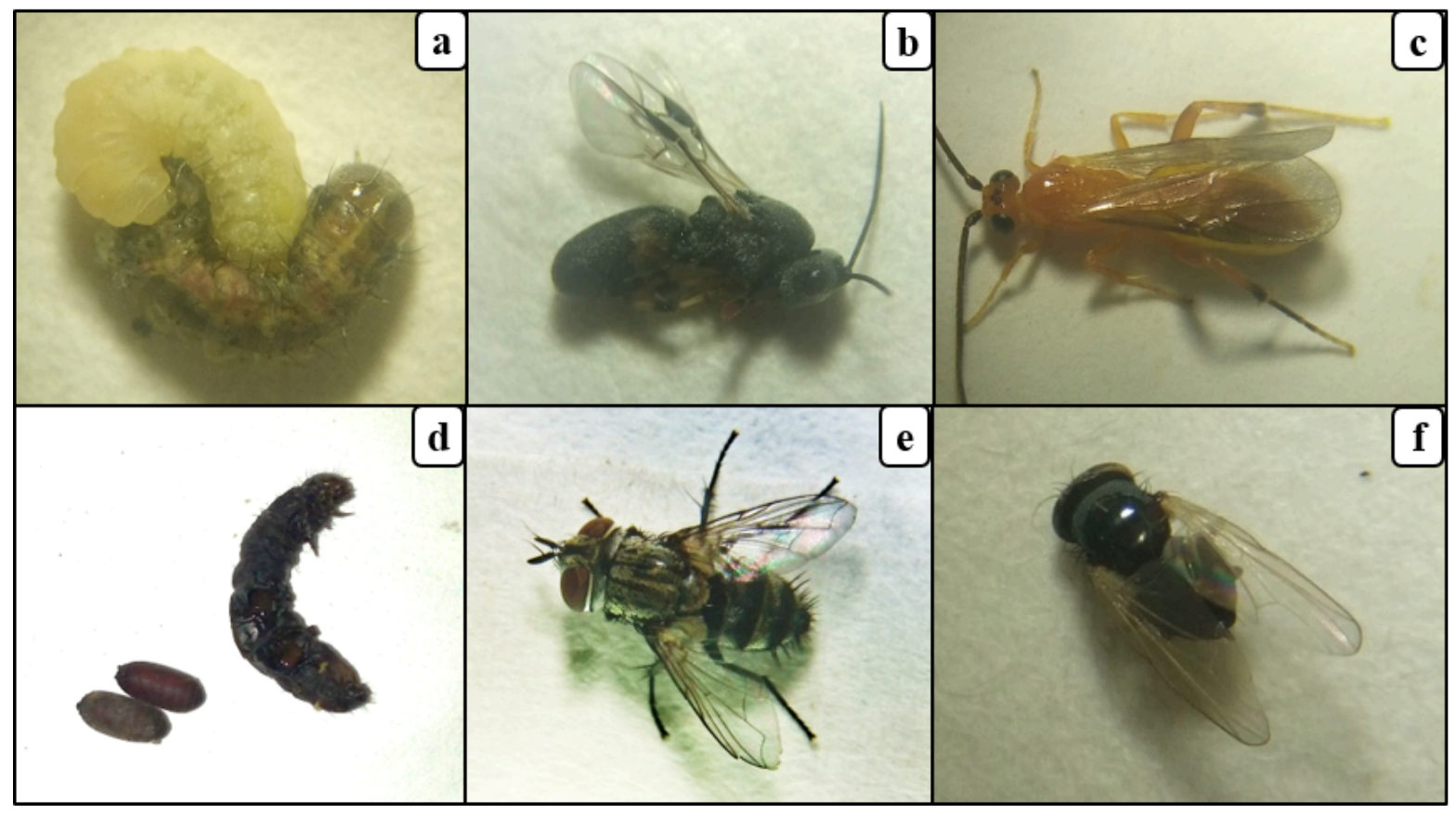

Figure 3: Parasitoids of fall armyworm in Burkina Faso

(a) larva of Chelonus bifoveolatus sucking the hemolymph from fall armyworm larva, (b) adult of C. bifoveolatus, (c) Coccygidium luteum, (d) pupae of gregarious larval endoparasitoid, (e) Drino sp., (f) unidentified Diptera

The present field survey data showed that $C$. bifoveolatus $(0.9 \%)$ and $C$. luteum (0.5\%) were the most abundant parasitoids in fall armyworm infested maize fields (Table 3).

Table 3: Parasitism rate (mortality rate) of fall armyworm attributed to various parasites, parasitoids, and other factors in Burkina Faso

\begin{tabular}{lc}
\hline Species & Parasitism rate (\%) \\
\hline Mermithid nematode & 8.2 \\
Chelonus bifoveolatus (Szépligeti) & 0.9 \\
Coccygidium luteum (Brullé) & 0.5 \\
Drino sp. & 0.5 \\
Unidentified sp. Diptera & 0.3 \\
Unidentified gregarious endoparasitoids & 0.2 \\
Total parasitism rate & 10.5 \\
Other mortality† & 7.4 \\
Total mortality & 17.9 \\
\hline
\end{tabular}

† Possible bacterial or viral agents and unknown death causes 
Natural enemies of the fall armyworm Spodoptera frugiperda (Smith) (Lepidopte...

\section{Predators}

In this study, a total of 736 arthropod predators belonging 13 species were recorded (Table 4).

Table 4: Host stages attacked and relative abondance (RA) of predators of fall armyworm, recorded in maize fields located in Burkina Faso

\begin{tabular}{|c|c|c|c|}
\hline $\mathbf{N}^{\circ}$ & Order, family and species of predator & Host stages attacked & RA (\%) \\
\hline \multirow[t]{3}{*}{1} & Araneae & Larvae & 5.4 \\
\hline & Coleoptera & & \\
\hline & Carabidae & & \\
\hline 2 & Calleida sp. & Larvae & 1.5 \\
\hline 3 & Unidentified sp. 1 & Larvae & 0.8 \\
\hline \multirow[t]{2}{*}{4} & Unidentified sp. 2 & Larvae & 0.4 \\
\hline & Coccinellidae & & \\
\hline 5 & Cheilomenes sulphurea (Olivier) & Larvae & 12.6 \\
\hline \multirow[t]{3}{*}{6} & Unidentified coccinelid & Larvae & 1.1 \\
\hline & Dermaptera & & \\
\hline & Forficulidae & & \\
\hline 7 & Diaperasticus erythrocephalus (Olivier) & Eggs and larvae & 26.8 \\
\hline \multirow[t]{2}{*}{8} & Forficula senegalensis (Serville) & Eggs and larvae & 24.3 \\
\hline & Hemiptera & & \\
\hline \multirow[t]{2}{*}{9} & Pentatomidae & Larvae & 2.3 \\
\hline & Reduviidae & & \\
\hline \multirow[t]{3}{*}{10} & Rhynocoris sp. & Larvae & 4.9 \\
\hline & Hymenoptera & & \\
\hline & Formicidae & & \\
\hline 11 & Pheidole megacephala (Fabricius) & Larvae & 5.6 \\
\hline \multirow[t]{2}{*}{12} & Unidentified spp. & Larvae & 10.2 \\
\hline & Mantodea & & \\
\hline 13 & Mantidae & Larvae & 4.1 \\
\hline
\end{tabular}

Earwigs represented up to $51 \%$ of the total predator complex identified from the maize fields. In many fields, earwigs are the most frequently encountered species, especially when free from insecticidal spray. All species found were Forficulidae of the species Diaperasticus erythrocephalus (Olivier) and Forficula senegalensis (Serville) (Fig. 4a-c). These two forficulidae are predators and 
were collected from late-stage maize fields, particularly in the whorl and ears of maize. We report the predation of fall armyworm larvae by the ant Pheidole megacephala (Fabricius) (Hymenoptera: Formicidae). Five additional ant species were observed on maize plants infested by fall armyworm. They were observed in all surveyed maize fields. Ladybirds constituted $13.7 \%$ of all predators recorded in maize fields.

Two species were found: Cheilomenes sulphurea (Olivier) and unidentified coccinelid (Coleoptera: Coccinellidae). Coccinellids were found active in fall armyworm infested maize fields and $C$. sulphurea was observed feeding on fall armyworm neonate larvae (Fig. 4f). The predators Calleida sp., two unidentified species (all Coleoptera: Carabidae) (Fig. 4h, i), Rhynocoris sp. (Hemiptera: Reduviidae) (Fig. 4m, n), and the order Areneae were found directly feeding on fall armyworm larvae in maize fields. Predation on fall armyworm larvae by Mantidae and Pentatomidae was not directly observed on maize plants. However, field collected specimens placed in boxes together with fall armyworm larvae were observed to devour them immediately (Fig. 4j-1). 


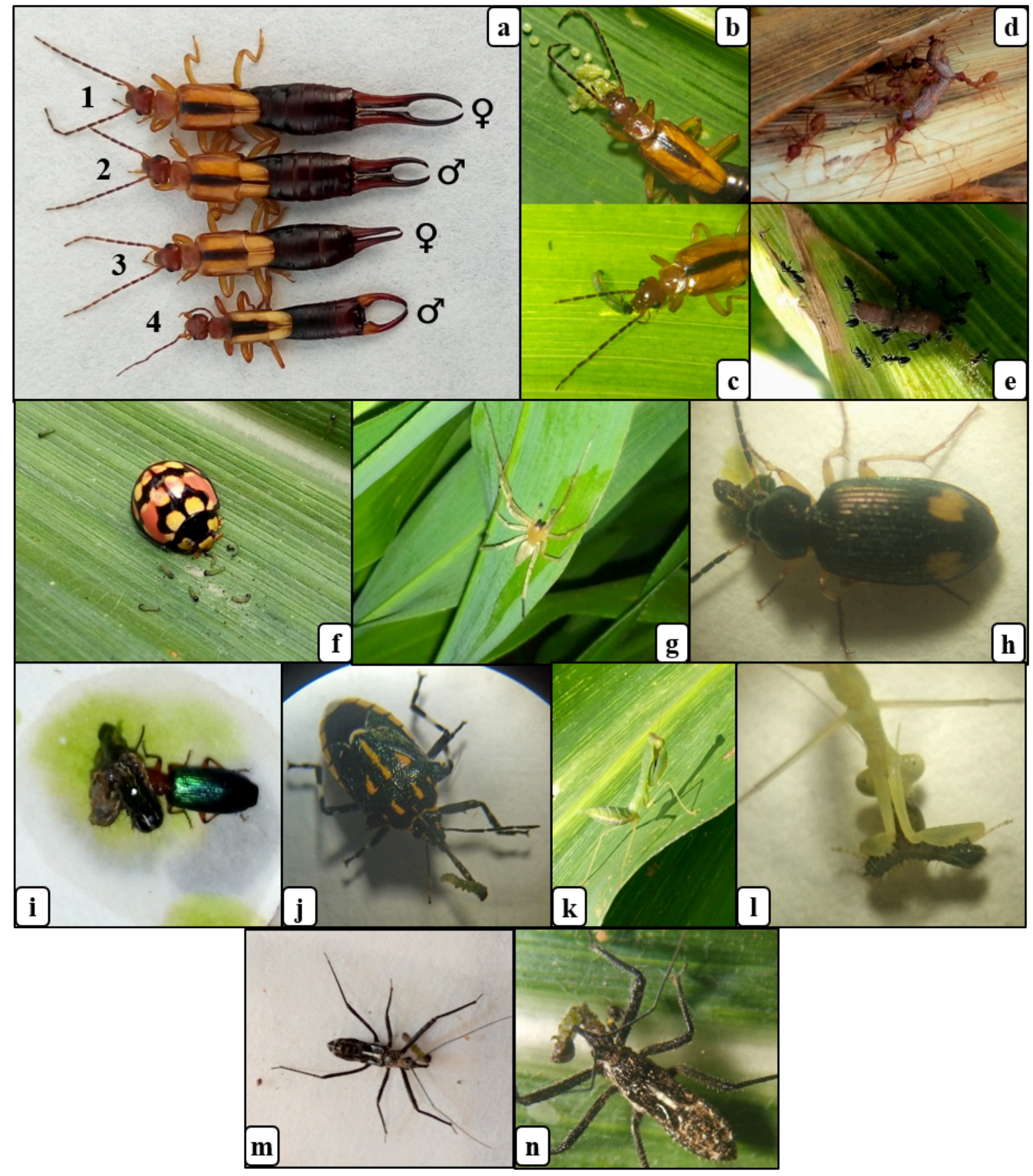

Figure 4: Predators of fall armyworm in Burkina Faso

(a) earwigs ( 1 and 2 = Forficula senegalensis, 3 and 4 = Diaperasticus erythrocephalus), (b, c) fall armyworm eggs and larvae attacked by earwig, (d, e) fall armyworm larvae attacked by ants, (f) fall armyworm larvae attacked by Cheilomenes sulphurea, (g) spider on a maize plant, (h) carabidae predator, (i) Calleida sp. eating fall armyworm larvae, (j) pentatomid predator eating a larva, $(\mathrm{k}, \mathrm{l})$ mantidae predator, $(\mathrm{m}, \mathrm{n})$ Rhynocoris sp. eating fall armyworm larvae

\section{Entomopathogenic fungus}

A total of 9 fall armyworm larvae infected with entomopathogenic fungus were collected from the fields (Fig. 5a), representing 1.4\% of larval infection. After incubating these cadavers on PDA 
medium (Fig. 5b), one fungus species was observed. Pathogenicity using Koch's postulates of fungi associated with fall armyworm collected in maize field revealed that the fungus was pathogenic to larvae. Mortality of larvae was recorded between 4 - 7 days after pathogenicity test (Fig. 5d). Identification and detailed description of the fungal strain is required.

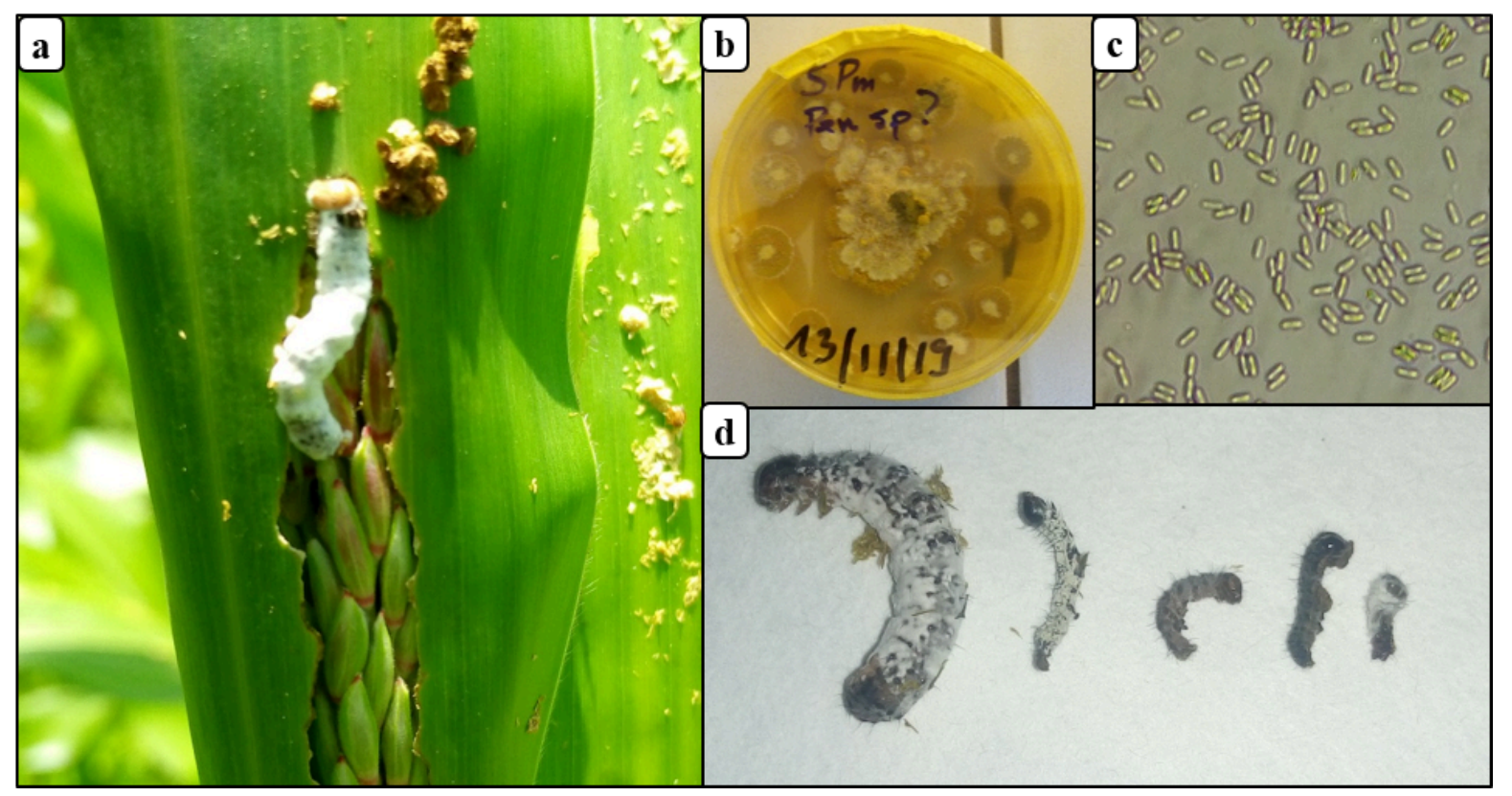

Figure 5: Entomopathogenic fungus of fall armyworm in Burkina Faso

(a) fall armyworm larva killed by an entomopathogenic fungus on maize, (b) momified fall armyworm larvae on PDA media, (c) conidia of entomopathogenic fungus, (d) fall armyworm larvae (3rd to 5th instar) killed by entomopathogenic fungus in the laboratory

Discussion

This study confirms the association of 20 species of natural enemies with the fall armyworm in Burkina Faso. Among them, 10 species were the first records of predation or parasitism on the fall armyworm in Burkina Faso. These were C. bifoveolatus, C. luteum (Hymenoptera: Braconidae), Drino sp. (Diptera: Tachinidae), D. erythrocephalus, F. senegalensis (Dermaptera: Forficulidae), $P$. megacephala (Hymenoptera: Formicidae), C. sulphurea (Coleoptera: Coccinellidae), Calleida sp. (Coleoptera: Carabidae), Rhynocoris sp. (Hemiptera: Reduviidae) and entomopathogenic nematode (Nematoda: Mermithidae).

The entomopathogenic nematode parasitism rate in Burkina Faso was lower than previous results in Senegal (13.7\%) where adult nematodes are shorter, 100 to $120 \mathrm{~mm}$ (18). Based on images shown by Tendeng et al. (18) and Firake \& Behere (22), these were likely also the same entomopathogenic nematode recently recovered from fall armyworm in Senegal and India, that the authors identified as Hexamermis sp. and Hexamermis cf. albicans (Siebold), respectively (all Nematoda: Mermithidae).

Parasitism rates of 30 and $9.8 \%$ of fall armyworms by Hexamermis were recorded in Nicaragua (40) and Honduras (19) respectively. Mermithid species feed on the insect host's haemolymph and then emerge to complete development outside it. Infective juveniles of mermithids climb on plants 
Natural enemies of the fall armyworm Spodoptera frugiperda (Smith) (Lepidopte...

in moist conditions, and infect hosts that feed on the plant (41). We also hypothesize that the soil placed into infested whorls of maize by growers, or which accidentally enters the whorl during manual weeding, may contain nematodes that infect the larvae. Additional studies are needed to identify and understand the ecological relationship between entomopathogenic nematodes and the fall armyworm with a view toward artificial rearing for field applications.

Fall armyworm larvae are susceptible to various parasitoids, corroborating earlier field reports in West Africa: Senegal (18), Benin and Ghana $(17,21)$. Many Chelonus species are generally solitary egg-larvae koinobiont endoparasitoids that attack Lepidoptera including S. littoralis, S. exigua, S. frugiperda and Heliothis virescens Fabricius (42). Chelonus spp. have recently been reported in the fall armyworm in several countries, C. curvimaculatus Cameron in Kenya (15), Chelonus sp. in Senegal (18) and C. bifoveolatus in Benin and Ghana $(17,21)$.

The braconid $C$. luteum is widely distributed in Africa and was firstly reported in association with the fall armyworm in Africa (Ethiopia, Kenya and Tanzania) $(15,43)$. This internal solitary koinobiont parasitoid was later reported in Benin and Ghana $(17,21)$ and Mozambique $(25)$. Several tachinid species in association with the fall armyworm were recently found in similar surveys conducted in several countries. Palexorista zonata (Curran) was recorded in East Africa (Ethiopia, Kenya) $(15,43)$ and Drino quadrizonula Thomson was recorded in West Africa (Benin, Ghana) (21). However, according to the recent classification of the Tachinidae of the Afrotropical region (31), D. quadrizonula is closely related to P. zonata. This species is prevalent in sub-Saharan Africa, and is known to attack a species of moth larvae such as: S. exigua, S. exempta and other noctuidae (32).

On the other hand, some unidentified species of Tachinidae were reported in Ghana (17), Mozambique (25) and India (22). These results suggest that these species are adapted to West African countries and can be good biological control agents of fall armyworm in West Africa. Considering the performance of parasitoids as biocontrol agents against fall armyworm in other parts of the world $(15,19,23)$, further studies are needed to evaluate their usefulness against fall armyworm in West Africa.

Most earwigs are generalist predators usually considered major component of the biological control complex agents for insect pests $(2,44)$. Earwigs (i.e. Doru luteipes (Scudder) and Euborellia anulipes (Lucas)) are used in biological control programs for maize and sorghum pests in Brazil (44). In Africa, earwigs are commonly reported as predators of aphids and stem borers in cereals (i.e. maize and rice) (2). In India, the earwig Forficula sp. was commonly found in maize whorls attacking different stages of fall armyworm $(4,20,22)$. The potential of these earwigs to predate on fall armyworm eggs and larvae needs to be investigated. In a similar study in Ghana, P. megacephala was the most abundant and dispersed predator of fall armyworm (17).

In Africa, Pheidole spp. are sufficiently common and widespread to suppress insects such as $H$. armigera (45). Similar to the present study, other coccinellids have recently been reported as predators of the fall armyworm in other countries: Harmonia octomaculata Fabricius and Coccinella transversalis Fabricius in India (20). However, Mantidae and Pentatomidae are known as common fall armyworm predators and have been reported in numerous previous studies $(16,22)$.

Entomopathogenic fungus can be effective in controlling fall armyworm populations $(2,22)$. Recently, larvae infected with the entomofungal pathogen Metarhizium (=Nomuraea) rileyi (Clavicipitaceae) were collected from some maize infested fields in India $(4,20,22)$. Moreover, Beauveria bassiana 
(Balsamo) Vuillemin was also recorded infesting fall armyworm larvae (22). Although fall armyworm cadavers showing natural symptoms of entomopathogenic fungi have been encountered in several fields in Africa, there are no published results in the scientific literature on the different entomopathogenic fungi associated with this new pest.

Temporal and spatial differences in fall armyworm parasitism and microbial infection may be caused by climate variability, agronomic practices, crop type and stage of cultivation (46). However, we hypothesize that this low parasitism rate of the fall armyworm is attributable to recent introductions of the parasite in Burkina Faso. Consequently, we believe that fall armyworm parasitism will increase provided that maize management includes options that conserve natural enemies. A balanced relationship between fall armyworm and its indigenous natural enemies may take considerable time to achieve, but the implementation of cultural practices that promote their action should be advocated (25).

\section{Conclusion}

An interesting conclusion of this study is that most natural enemies are abundant in maize fields and their potential should be exploited to control the fall armyworm. The indiscriminate use of chemical insecticides against fall armyworm negatively affects the natural enemies and can undermine the management strategies of smallholder farmers who rely heavily on natural enemies. The use of selective insecticides, protection of natural enemies from the harmful effects of insecticides and the development of more comprehensive integrated pest management strategies for the management of fall armyworm in Burkina Faso are therefore crucial.

\section{Acknowledgements}

This research was funded by the Academy of Research and Higher Education-Commission Development Cooperation (ARES-CDD) as part of the PRD AGRO-ECO project. The authors would wish to express their thanks and gratitude to the farmers and extension officers who made the study a success.

\section{Bibliographie}

1. Goergen G., Kumar P.L., Sankung S.B., Togola A. \& Tamò M., 2016, First report of outbreaks of the fall armyworm Spodoptera frugiperda (J E Smith) (Lepidoptera, Noctuidae), a new alien invasive pest in West and Central Africa. PLoS One 11(10), e0165632. https://doi.org/10.1371/journal.pone.0165632

2. Montezano D.G., Specht A., Sosa-Gómez D.R., Roque-Specht V.F., Sousa-Silva J.C., PaulaMoraes S. V, Peterson J.A. \& Hunt T.E., 2018. Host plants of Spodoptera frugiperda (Lepidoptera: Noctuidae) in the Americas. African Entomol. 26(2), 286-300. https://doi.org/10.4001/003.026.0286

3. Prasanna B.M., Huesing J.E., Eddy R. \& Peschke V.M. (Eds.), 2018, Fall armyworm in Africa: A guide for integrated pest management, First edition, Mexico, CDMX: CIMMYT, $120 \mathrm{p}$.

4. Shylesha A.N., Jalali S.K., Gupta A., Varshney R., Venkatesan T., Shetty P., Ojha R., 
Natural enemies of the fall armyworm Spodoptera frugiperda (Smith) (Lepidopte...

Ganiger P.C., Navik O., Subaharan K., Baktavatsalam N. \& Ballal C.R., 2018, Studies on new invasive pest Spodoptera frugiperda (J. E. Smith) (Lepidoptera: Noctuidae) and its natural enemies. J. Biol. Control 32(3). https://doi.org/10.18311/jbc/2018/21707

5. Sharanabasappa, Kalleshwaraswamy C.M., Asokan R., Swamy H.M.M., Maruthi M.S., Pavithra H.B., Hegde K., Navi S., Prabhu S.T. \& Goergen G., 2018, First report of the fall armyworm, Spodoptera frugiperda (J E Smith) (Lepidoptera: Noctuidae), an alien invasive pest on maize in India. Pest Manag. Hortic. Ecosyst. 24(1), 23-29.

6. Day R.K., Abrahams P., Bateman M.L., Beale T., Clottey V., Cock M.J.W., Colmenarez Y., Corniani N., Early R., Godwin J., Gomez J., Moreno P.G., Murphy S.T., Oppong-Mensah B., Phiri N.A., Pratt C., Silvestri S. \& Witt A., 2017, Fall armyworm: Impacts and implications for Africa. Outlooks Pest Manag. 28(5), 196-201. https://doi.org/10.1564/v28_oct_02

7. Harrison R.D., Thierfelder C., Baudron F., Chinwada P., Midega C.A.O., Schaffner U. \& van den Berg J., 2019, Agro-ecological options for fall armyworm (Spodoptera frugiperda JE Smith) management: Providing low-cost, smallholder friendly solutions to an invasive pest. J. Environ. Manage. 243, 318-330. https://doi.org/10.1016/j.jenvman.2019.05.011

8. Sisay B., Tefera T., Wakgari M., Ayalew G. \& Mendesil E., 2019, The efficacy of selected synthetic insecticides and botanicals against fall armyworm, Spodoptera frugiperda, in maize. Insects 10(45), 1-14. https://doi.org/10.3390/insects10020045

9. Ahissou B.R., Sawadogo W.M., Bokonon-Ganta A.H., Somda I., Kestemont M.-P. \& Verheggen F.J., 2021, Baseline toxicity data of different insecticides against the fall armyworm Spodoptera frugiperda (J.E. Smith) (Lepidoptera: Noctuidae) and control failure likelihood estimation in Burkina Faso. African Entomol. 29(2) 435-444. https://doi.org/10.4001/003.029.0435

10. Son D., Somda I., Legreve A. \& Schiffers B., 2017, Pratiques phytosanitaires des producteurs de tomates du Burkina Faso et risques pour la santé et l'environnement. Cah. Agric. 26(2). https://doi.org/10.1051/cagri/2017010

11. Nafiu B.S., Dong H. \& Mustapha S., 2014, Biological control of insect pests in West Africa: A review. Int. J. Appl. Res. Technol. 3(9), 39-45. https://doi.org/10.13140/

RG.2.2.13034.31687

12. van Lenteren J.C., Bolckmans K., Köhl J., Ravensberg W.J. \& Urbaneja A., 2018, Biological control using invertebrates and microorganisms: plenty of new opportunities. BioControl 63, 39-59. https://doi.org/10.1007/s10526-017-9801-4

13. Barbosa P. \& Benrey B., 1998, The influence of plants on insect parasitoids: Implications for conservation biological control. In: Conservation Biological Control. 55-82. https://doi.org/10.1016/B978-012078147-8/50050-5

14. Molina-Ochoa J., Carpenter J.E., Heinrichs E.A. \& Foster J.E., 2003, Parasitoids and parasites of Spodoptera frugiperda (Lepidoptera: Noctuidae) in the Americas and Caribbean Basin: an inventory. Florida Entomol. 86(3), 254-289. https://doi.org/10.1653/ 0015-4040(2003)086[0254:PAPOSF]2.0.CO;2 
15. Sisay B., Simiyu J., Malusi P., Likhayo P., Mendesil E., Elibariki N., Wakgari M., Ayalew G. \& Tefera T., 2018, First report of the fall armyworm, Spodoptera frugiperda (Lepidoptera: Noctuidae), natural enemies from Africa. J. Appl. Entomol. 142, 800-804. https://doi.org/ 10.1111/jen.12534

16. Wyckhuys K.A.G. \& O’Neil R.J., 2006, Population dynamics of Spodoptera frugiperda Smith (Lepidoptera: Noctuidae) and associated arthropod natural enemies in Honduran subsistence maize. Crop Prot. 25, 1180-1190. https://doi.org/10.1016/ j.cropro.2006.03.003

17. Koffi D., Kyerematen R., Eziah V.Y., Agboka K., Adom M., Goergen G. \& Meagher R.L., 2020, Natural enemies of the fall armyworm, Spodoptera frugiperda (J.E. Smith) (Lepidoptera: Noctuidae) in Ghana. Florida Entomol. 103(1), 85-90. https://doi.org/ 10.1653/024.103.0414

18. Tendeng E., Labou B., Diatte M., Djiba S. \& Diarra K., 2019, The fall armyworm Spodoptera frugiperda (J. E. Smith), a new pest of maize in Africa: biology and first native natural enemies detected. Int. J. Biol. Chem. Sci. 13(2), 1011-1026. https://doi.org/ 10.4314/ijbcs.v13i2.35

19. Wheeler G.S., Ashley T.R. \& Andrews K.L., 1989, Larval parasitoids and pathogens of the fall armyworm in Honduras maize. Entomophaga 34(3), 331-340. https://doi.org/10.1007/ $\underline{B F 02372472}$

20. Sharanabasappa, Kalleshwaraswamy C.M., Poorani J., Maruthi M.S., Pavithra H.B. \& Diraviam J., 2019, Natural enemies of Spodoptera frugiperda (J. E. Smith) (Lepidoptera: Noctuidae), a recent invasive pest on maize in South India. Florida Entomol. 102(2), 619623.

21. Agboyi L.K., Goergen G., Beseh P., Mensah S.A., Clottey V.A., Glikpo R., Buddie A., Cafà G., Offord L., Day R.K., Rwomushana I. \& Kenis M., 2020, Parasitoid complex of fall armyworm, Spodoptera frugiperda, in Ghana and Benin. Insects 11(68), 1-15. https://doi.org/10.3390/insects11020068

22. Firake D.M. \& Behere G.T., 2020, Natural mortality of invasive fall armyworm, Spodoptera frugiperda (J. E. Smith) (Lepidoptera: Noctuidae) in maize agroecosystems of northeast India. Biol. Control 148, 1-11. https://doi.org/10.1016/j.biocontrol.2020.104303

23. Kenis M., du Plessis H., Van den Berg J., Ba M.N., Goergen G., Kwadjo K.E., Baoua I., Tefera T., Buddie A., Cafà G., Offord L., Rwomushana I. \& Polaszek A., 2019, Telenomus remus, a candidate parasitoid for the biological control of Spodoptera frugiperda in Africa, is already present on the continent. Insects 10(92), 1-10. https://doi.org/10.3390/ insects10040092

24. Laminou S., Ba M.N., Karimoune L., Doumma A. \& Muniappan R., 2020, Parasitism of locally recruited egg parasitoids of the fall armyworm in Africa. Insects 11(430), 1-13. https://doi.org/10.3390/insects11070430

25. Caniço A., Mexia A. \& Santos L., 2020, First report of native parasitoids of fall armyworm Spodoptera frugiperda Smith (Lepidoptera: Noctuidae) in Mozambique. Insects 11(615), 
Natural enemies of the fall armyworm Spodoptera frugiperda (Smith) (Lepidopte...

\section{1-12. https://doi.org/10.3390/insects11090615}

26. Dicko I.O., Dao B., Nénon J.P., Traoré S. \& Coderre D., 1998, Evaluation des connaissances paysannes sur la diversité de l'entomofaune du sorgho et de l'arachide au Burkina Faso. Agric. Développement 20, 25-32.

27. Baker G.L. \& Capinera J.L., 1997, Nematodes and nematomorphs as control agents of grasshoppers and locusts. Mem. Entomol. Soc. Canada 129, 157-211. https://doi.org/ 10.4039/entm129171157-1

28. Braet Y., Rousse P. \& Sharkey M.J., 2012, New data on African Cheloninae (Hymenoptera, Braconidae) show a strong biogeographic signal for taxa with spined propodea. Zootaxa 3385(1), 1-32. https://doi.org/10.11646/zootaxa.3385.1.1

29. Sharkey M.J., 1992, Cladistics and tribal classification of the Agathidinae (Hymenoptera: Braconidae). J. Nat. Hist. 26, 425-447. https://doi.org/10.1080/00222939200770251

30. van Achterberg C., 1990, Illustrated key to the subfamilies of the Holarctic Braconidae (Hymenoptera: Ichneumonoidea). Zool. Meded. Leiden 64(1-6), 1-20.

31. O'Hara J.E. \& Cerretti P., 2016, Annotated catalogue of the Tachinidae (Insecta, Diptera) of the Afrotropical Region, with the description of seven new genera. Zookeys 575, 1-344. https://doi.org/10.3897/zookeys.575.6072

32. Crosskey R.W., 1968, The identity of Palexorista quadrizonula (Thomson) (Diptera), a Tachinid parasite of Lepidopterous pests in Africa. Bull. Entomol. Res. 59(4), 579-583. https://doi.org/10.1017/S0007485300003564

33. Girod C. \& Lassalle B., 2017, Liste annotée des Perce-oreilles du Tchad (Dermaptera). Bull. la Société Entomol. Fr. 122(2), 161-168.

34. Brindle A., 1967, A key to the Ethiopian genus Diaperasticus Burr (Dermaptera: Forficulidae). Proc. R. Entomol. Soc. Ser. B 36(9-10), 147-152. https://doi.org/10.1111/ j.1365-3113.1967.tb00552.x

35. Waller A., Caussanel C., Jamet C. \& Albouy V., 1999, Etude comparée des pièces thoraciques et de leurs appendices chez quelques Dermaptères. Bull. la Société Entomol. Fr. 104(5), 427-440.

36. Nicolas V., Coutanceau J.P., Poussereau J. \& Gomy Y., 2015, Les Coccinelles de l'île de La Réunion. In: Actes Des «Premières Rencontres Nationales Des Coccinellistes 》 - Angers, 2014. 157-186.

37. Kwadjo K.E., Doumbia M. \& Haubruge E., 2012, Description et distinction des larves et des exuvies de Rhynocoris albopilosus Signoret (Heteroptera: Reduviidae). Entomol. Faun. - Faun. Entomol. 65, 15-23. https://popups.uliege.be/2030-6318/ index.php?id=2295

38. Molina-Ochoa J., Carpenter J.E., Lezama-Gutiérrez R., Foster J.E., González-Ramírez M., Angel-Sahagún C.A. \& Farías-Larios J., 2004, Natural distribution of hymenopteran parasitoids of Spodoptera frugiperda (Lepidoptera: Noctuidae) larvae in Mexico. Florida 
Entomol. 87(4), 461-472. https://doi.org/10.1653/

0015-4040(2004)087[0461:NDOHPO]2.0.CO;2

39. Pair S.D., Raulston J.R., Sparks A.N. \& Martin P.B., 1986, Fall armyworm (Lepidoptera: Noctuidae) parasitoids: Differential spring distribution and incidence on corn and sorghum in the Southern United States and Northeastern Mexico. Environ. Entomol. 15(2), 342-348. https://doi.org/10.1093/ee/15.2.342

40. van Huis A., 1981, Integrated pest management in the small farmer's maize crop in Nicaragua. Meded. Landbouwhogesch. Wageningen 81(6), 222.

41. Nickle W.R., 1981, Mermithid Parasites of Agricultural Pest Insects. J. Nematol. 13(3), 262-266.

42. Grossniklaus-Bürgin C., Wyler T., Pfister-Wilhelm R. \& Lanzrein B., 1994, Biology and morphology of the parasitoid Chelonus inanitus (Braconidae, Hymenoptera) and effects on the development of its host Spodoptera littoralis (Noctuidae, Lepidoptera). Invertebr. Reprod. Dev. 25(2), 143-158. https://doi.org/10.1080/07924259.1994.9672379

43. Sisay B., Simiyu J., Mendesil E., Likhayo P., Ayalew G., Mohamed S., Subramanian S. \& Tefera T., 2019, Fall armyworm, Spodoptera frugiperda infestations in East Africa: Assessment of damage and parasitism. Insects 10(195), 1-10. https://doi.org/10.3390/ insects10070195

44. Cruz I., 2007, Controle Biológico de Pragas na Cultura de Milho para Produção de Conservas (Minimilho), por Meio de Parasitóides e Predadores. Circ. Técnico 91. Embrapa Milho e Sorgo, Sete Lagoas, Brazil 1-16.

45. Van Den Berg H., Cock M.J.W., Oduor G.I. \& Onsongo E.K., 1993, Incidence of Helicoverpa armigera (Lepidoptera: Noctuidae) and its natural enemies on smallholder crops in Kenya. Bull. Entomol. Res. 83, 321-328. https://doi.org/10.1017/ $\underline{\text { S0007485300029205 }}$

46. Ruiz-Nájera R.E., Molina-Ochoa J., Carpenter J.E., Espinosa-Moreno J.A., Ruiz-Nájera J.A., Lezama-Gutiérrez R. \& Foster J.E., 2007, Survey for Hymenopteran and Dipteran parasitoids of the fall armyworm (Lepidoptera: Noctuidae) in Chiapas, Mexico. J. Agric. Urban Entomol. 24(1), 35-42. https://doi.org/10.3954/1523-5475-24.1.35

PDF généré automatiquement le 2023-04-26 15:38:37

Url de l'article : https://popups.uliege.be/2295-8010/index.php?id=1881 